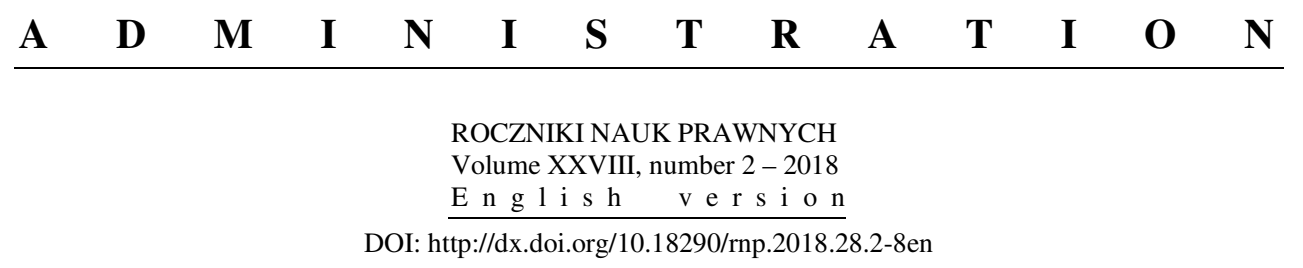

SŁAWOMIR ZWOLAK

\title{
THE FREEDOM OF CONSTRUCTION AND OBLIGATIONS TO MAINTAIN BUILDING STRUCTURES
}

\section{INTRODUCTION}

The aim of the study is to present the idea of the freedom of construction in the context of obligations imposed on the owner and the administrator of a building structure while it is in use. So far, the relevant literature has not addressed the way the freedom of construction principle is reflected in the legal regulations governing the duties of the owner or administrator. At the moment, there is an urgent need to explore this subject area, not only in connection with the ongoing legislative work concerning an urban-planning and construction code, but mainly the numerous amendments to the Construction Law which impose new obligations concerning the maintenance of building structures.

\section{THE EXTENT AND NATURE OF THE FREEDOM OF CONSTRUCTION}

The principle of freedom of construction is reflected normatively by Article 4 of the Act of 7 July 1994 (The Construction Law), ${ }^{1}$ which states that everyone has the right to develop a land property if he or she demonstrates the title to use the property for construction purposes, as long as the

\footnotetext{
SŁawomir ZwolaK, PhD, works at the Department of Administrative Law, Institute of Law, Faculty of Law, Canon Law and Administration of the John Paul II Catholic University of Lublin (KUL); address: Al. Racławickie 14, 20-950 Lublin, Poland; e-mail: sla_z@poczta.fm

${ }^{1}$ Journal of Laws of 2017, item 1332 as amended [hereinafter referred to as CL].
} 
intended construction project complies with the applicable regulations. ${ }^{2}$ The significance of this principle for the individual people is obvious, as it serves to protect the entities involved in the construction process. ${ }^{3}$ The freedom of construction is therefore a public subjective right enjoyed by everyone who has the right to use of real estate for construction purposes. ${ }^{4}$

The concept of the freedom of construction should be understood as a domain of unrestricted activities related to the exercise of the ownership right to real estate related to the construction, repair, maintenance and demolition of a building structure. ${ }^{5}$ Therefore, we can say that the freedom of construction principle, as envisaged by the Act, has the features of the main principle covering issues related to the development and subsequent use of a building structure. The freedom of construction also consists in not hindering the owners of neighbouring properties in their conduct of equivalent activities whenever they desire. Since the freedom of construction is not absolute, it is protected by ensuring that the limits imposed by the legal norms are not overstepped. ${ }^{6}$

The substance of the freedom of construction may be interpreted in terms of various specific freedoms related to human activity, which are primarily: the freedom to undertake construction activities and freedom to use a building structure. ${ }^{7}$ This principle also gives rise to certain obligations imposed on administrative bodies, whose purpose is to resolve doubts based on the legal presumption of building freedom and the ban on extending the interpretation of exceptions to the principle of freedom of construction. Moreover, the catalogue of their duties should include the creation of material conditions fostering the freedom of construction. According to the Constitutional

\footnotetext{
${ }^{2}$ Zdzisław Kostka points out an interpretative inconsistency demonstrated by Article 4 CL. He argues that the provision contains a declaration of the freedom of development, which for some strange reason is limited only to the development of real estate, leaving out construction works in other premises known to the Polish legal system, namely in premises and buildings which, pursuant to specific regulations, constitute objects of ownership separate from land. Z. KostKA, Prawo budowlane. Komentarz (Gdańsk: Ośrodek Doradztwa i Doskonalenia Kadr, 2005), 23.

${ }^{3}$ Z. LEOŃSKI, "Zasada wolności budowlanej i jej administracyjnoprawne ograniczenia," in Rola materialnego prawa administracyjnego a ochrona praw jednostki, ed. Z. Leoński (Poznań: Wydawnictwo Wyższej Szkoły Bankowej, 1998), 141.

${ }^{4}$ H. KisILOWSKA and D. SYPNIEWSKI, Prawo budowlane (Warszawa: LexisNexis, 2012), 63.

${ }^{5}$ K. ZAMYŚLEWSKA-GORZĄCH, “Wolność budowlana i jej prawne ograniczenia," Samorząd Terytorialny 10 (2005): 57.

${ }^{6}$ KisilowsKa and SyPNiEwSKI, Prawo, 64; Judgement of the Supreme Administrative Court of 18 January 2008, file ref. no. II OSK 1876/06, LEX no. 508458.

${ }^{7}$ M. ZDYB, Wspólnotowe i polskie prawo publiczne, vol. 1, Wolność i reglamentacja działalności gospodarczej. Handel zagraniczny (Warszawa: Wolters Kluwer, 2008), 39.
} 
Tribunal, the freedom of construction principle is expressed in two categories. First of all, in the material sense, it provides guidance as to the interpretation of construction law regulations governing the investment and construction process. ${ }^{8}$ Secondly, in the subjective sense, the freedom of construction principle ${ }^{9}$ can be understood as the right to develop estate, which springs from the freedom of construction, which is an emanation of the right of ownership. ${ }^{10}$ As underscored by the Constitutional Tribunal, the right to develop estate has both a civil law aspect and a public law one. ${ }^{11}$ As regards the former, the right to develop estate is secondary to the right of real estate ownership, as well as another property right of a material or even obligatory nature, which embraces the "right to use real estate for construction purposes." This disposition is intended to ensure order and protection of ownership, preventing other people conducting construction works on one's own land. ${ }^{12}$ It is worth noting the nature of the constitutional regulations concerning rights to things, including real property. The strongest right of this kind is the right of ownership. If we assume that the right to develop estate is linked to the ownership right, the nature of the former right requires that we first look at the constitutional regulation of the right of ownership. ${ }^{13}$ For this

\footnotetext{
${ }^{8}$ Z. LEOŃSKI and M. SZEWCZYK, Podstawowe instytucje planowania przestrzennego i prawa budowlanego (Poznań: Wydawnictwo Wyższej Szkoły Bankowej, 1999), 37-38.

${ }^{9}$ See D. SYPNIEWSKI, Nadzór nad procesem budowlanym (Warszawa: LexisNexis, 2011), 61; Z. NiEWIADOMSKI and T. ASMAN, "Wolność budowlana jako prawo podmiotowe inwestora," in Księga jubileuszowa profesora Stanistawa Jędrzejewskiego, ed. H. Nowicki and W. Szwajdler (Toruń: Towarzystwo Naukowe Organizacji i Kierownictwa "Dom Organizatora", 2009), 571.

${ }^{10}$ Judgement of the Constitutional Tribunal of 23 April 2011, file ref. no. Kp 7/09, OTK-A 2011, no. 3, item 26; W. JAKIMOWICZ, Wolność zabudowy w prawie administracyjnym (Warszawa: Wolters Kluwer Polska, 2012), 48-49. M. Laskowska presents a different view on that claiming that "the present notion of the freedom of construction has been separated from the notion of the ownership right." See M. LASKOwSKA, "Ochrona interesów sąsiadów w procesie budowy po nowelizacji," Samorzad Terytorialny 5 (2004): 48-49.

${ }^{11}$ T. Asman and Z. Niewiadomski, "Komentarz do art.4," in Prawo budowlane. Komentarz, ed. Z. Niewiadomski (Warszawa: Wydawnictwo C.H. Beck, 2011), 92-93. A. Mączyński claims that in the area of civil law, ownership is a subjective right, while ownership as defined in Article 64 of the Polish Constitution belongs to the category of public rights vested in an individual towards the State. A. MĄCZYŃSKI, "Prawo do mieszkania w świetle Konstytucji RP," in Godność człowieka a prawa ekonomiczne $i$ socjalne. Księga jubileuszowa wydana w piętnasta rocznicę ustanowienia Rzecznika Praw Obywatelskich (Warszawa: Wydawnictwo RPO, 2003), 143.

${ }^{12}$ M. KRuszYŃSKA-KoŚMicKA and M. KRUŚ, "Prawne ograniczenia wolności budowlanej," in Prawo wobec wyzwań wspótczesności, ed. B. Guzik, N. Buchowska, and P. Wiliński (Poznań: Biuro Usługowo-Handlowe "PRINTER", 2010), 4:391.

${ }^{13}$ W. JAKIMOWICZ, "Przestrzeń prawna wolności zabudowy," in Przestrzeń w prawie administracyjnym. III krakowsko-wrocławskie spotkanie naukowe administratywistów, ed. J. Zimmermann (Warszawa: Wolters Kluwer, 2013), 54.
} 
reason, the Constitutional Tribunal assumed that the civil law right to develop real estate stems indirectly from Article 64 of the Constitution of the Republic of Poland, ${ }^{14}$ the latter guaranteeing the right of ownership, other property rights and the right of inheritance. ${ }^{15}$ Furthermore, the Tribunal stated that all enjoy the same legal protection and that property may be restricted only by statue and only insofar as it does not affect the essence of ownership. A similar position was expressed by the Supreme Administrative Court, which reasoned that the freedom of construction constitutes a development of the constitutional principle of property protection under the Construction Law (Article 21 para. 1 and Article 64 para. 3 of the Constitution). ${ }^{16}$ In contrast, with regard to the public-law aspect, we should assume that the cases when the right of ownership is limited under the Construction Law apply to those spheres of ownership which have been infringed and include all public-law restrictions of the right of ownership, while at the same time we should consider them as cases where restrictions on the right of ownership are shaped. ${ }^{17}$ The right to develop real estate, which is a component of the ownership right to real estate, is shaped primarily by public law, the norms of which are enshrined mainly in the provisions of the broadly understood construction law together with the technical and construction regulations.

The provision of Article $4 \mathrm{CL}$ belongs not only in the sphere of administrative law but it is also part of civil law. Therefore, it is hard to ignore the fact that the provisions of the Civil Code, including those concerning the use of real estate-which in principle regulate the relations between the owners of real estate and to a limited extent - apply to relations between subjects of other property rights or obligations. ${ }^{18}$ If a conflict develops between the investor's right to develop real estate and the rights of users of adjacent real estate, Article 64 para. 2 of the Polish Constitution guarantees equal legal protection of ownership and other property rights to all citizens. The essence

\footnotetext{
${ }^{14}$ Constitution of the Republic of Poland of 2 April 1997, Journal of Laws No. 78, item 483, as amended.

${ }^{15}$ See also KostKa, Prawo budowlane, 23.

${ }^{16}$ Judgement of the Supreme Administrative Court of 23 February 2007, case ref. II OSK 354/06, LEX no. 505624; Judgment of the Supreme Administrative Court of 18 January 2008, file ref. no. II OSK 1876/06.

${ }^{17}$ See also A. WASILEWSKI, "Administracja wobec prawa własności nieruchomości gruntowych. Rozważania z zakresu nauki prawa administracyjnego," Zeszyty Naukowe Uniwersytetu Jagiellońskiego 54 (1972): 53-54.

${ }^{18}$ Judgement of the Constitutional Tribunal of 23 April 2011, file ref. no. Kp 7/09.
} 
of this guarantee is the protection of ownership and other property rights, an assurance which cannot be differentiated with respect to the type of subject of a given right, and the necessity to protect third party rights is one of the reasons for introducing statutory restrictions to the investor's rights and interference of administrative bodies in the development of real estate, both prior to the commencement of construction works, during and after their completion. ${ }^{19}$ The guarantee-oriented character of Article $4 \mathrm{CL}$ causes that the right to develop real estate vested in the investor ${ }^{20}$ or owner is offset by the protection of third party rights and the public interest. In this case, the legislator is guided by the concern for a proper, harmonious co-existence of members of society, which applies both to the protection of the interests of individuals and certain social goods, including public property. ${ }^{21}$ Where there exists a restriction for the sake of public interest, this guarantee implies that the restriction cannot be arbitrary. Only by way of statute can certain organizational and legal forms of construction activity be modified, which creates different legal effects. The existing legal norms in themselves cannot extinguish the freedom of construction. ${ }^{22}$ If we try to define the order of values functioning in the construction industry, we will see that the freedom of construction appears to be a commitment to observe this order. At this point, we can note that it is a component of the objective legal order in the area of building construction. No doubt, then, that the essence of the principle of freedom of construction results from the need for constitutional protection of the right of ownership. ${ }^{23}$

\footnotetext{
${ }^{19}$ JAKIMOWICZ, Wolność zabudowy, 64-65.

${ }^{20}$ It should be noted that the right to develop real estate is in fact a legal instrument for the protection of the freedom of construction. An investor whose building project is compliant with the provisions of the Construction Law and who presents the right to use the real estate for construction purposes, will obtain, under Art. 4 CL, a statutory guarantee that his freedom of construction will be satisfied. KRUSZYŃSKA-KOŚMICKA and KRUŚ, "Prawne ograniczenia," 392.

${ }^{21}$ Judgement of the Constitutional Tribunal of 12 January 1999, file ref. no. P 2/98, OTK of 1999, no. 1, item 2. According to Wojciech Piątek, the principle of freedom of construction must not be in conflict with other values enshrined in the Constitution. W. PiĄTEK, "Komentarz do art. 4," in Prawo budowlane. Komentarz, ed. A. Gliniecki (Warszawa: Wydawnictwo C.H. Beck, 2012), 54.

${ }^{22}$ Compare Prawo gospodarcze. Zagadnienia administracyjnoprawne, ed. M. Wierzbowski and M. Wyrzykowski (Warszawa: LexisNexis, 2015), 48-49.

${ }^{23}$ Z. LEOŃSKI, Materialne prawo administracyjne (Warszawa: Wydawnictwo C.H. Beck, 2005), 120. W. JAKIMOWICZ, "Konstrukcja i istota wolnościowego prawa do zabudowy," Samorzad Terytorialny 6 (2005): 47; KISILOWSKA and SYPNIEWSKI, Prawo, 63; D. SYPNIEWSKI, "Deregulacja procesu inwestycyjno-budowlanego. Ograniczenie reglamentacji robót budowlanych," Przegląd Prawa Publicznego 2 (2013): 76; Z. CZARNIK, "Miejscowy Plan zagospodarowania przestrzennego jako podstawy wykonywania własności nieruchomości," Zeszyty Naukowe Sądownictwa Administracyjnego
} 


\section{OBLIGATIONS CONCERNING THE MAINTENANCE OF BUILDING STRUCTURES}

An obligation is first of all a necessity to do something, resulting from a norm. The essence of an obligation in administrative law implies interest and an addressee of a given obligation and its substantive aspect. From the subjective point of view, this obligation consists in acting, refraining or suppressing. ${ }^{24}$ Under administrative law, the existence of an obligation relates primarily to substantive law but also to procedural law. Material and legal obligations determine the administrative and legal status of a citizen; they are characterised by permanence and independence.

Obligations existing during the use of construction works are addressed by many legal acts, however, the Construction Law specifies them in their fullest form. The Act, in particular Chapter 6, imposes obligations on property owners with respect to the maintenance of building structures. The term "maintenance" refers to a combination of technical measures and related administrative actions taken throughout the life-cycle in order to maintain a building or parts thereof in a state in which it can perform its intended functions. Even more precisely, the term "maintenance" can be defined as actions that help to achieve the designed service life, including cleaning, maintenance, operation, repairs, upgrades, security, administration, usage controls and avoidance of negligence. ${ }^{25}$ Having regard to those terms, it can be assumed that the term "maintenance of building structures should be taken to mean the maintenance of building structures in good working order, including maintenance in an unaltered, not deteriorated and condition. ${ }^{26}$

2 (2006): 44; B. MAJCHRZAK, Procedura zgłoszenia robót budowlanych (Warszawa: Wolters Kluwer, 2008), 27.

${ }^{24}$ P. SZRENIAWSKI, Obowiazek $w$ prawie administracyjnym (Lublin: Wydawnictwo WSPA, 2014), 24-25. According to Piotr Przybysz, an administrative duty is an order of specified behaviour issued by a state authority within its competence and in a proper form, addressed to a citizen. This order concerns a matter regulated by the norms of administrative law. P. PRZYBYSZ, "Obowiązek administracyjny - pojęcie, rodzaje," Organizacja-Metody-Technika 8-9 (1990): 14.

${ }^{25}$ Z. ORŁOWSKI, "Wybrane aspekty właściwości użytkowych budynku w okresie jego eksploatacji," Przeglad Budowlany 10 (2011): 42. In the opinion of the Voivodeship Court of Appeal in Kielce, the term "maintenance" should be understood as the maintenance of an object in a good, unaltered, and proper technical condition. See the Judgement of the Voivodeship Court of Appeal in Kielce of 29 April 2013, file ref. no. II Aka 144/13, LEX no. 1325739.

${ }^{26}$ Judgement of the Voivodship Court of Appeal in Warszawa of 22 May 2007, file ref. no. VII SA/Wa 2298/06, LEX no. 336729. 
Pursuant to the Construction Law, the entities responsible for ensuring proper maintenance of building structures are the owner and manager (Article $61 \mathrm{CL}$ ). This means that an obligation is imposed on two entities, one of which relieves the other entity of the obligation. However, this obligation rests first and foremost with the owner. In addition, the list of entities responsible in terms of the notion of real estate, as defined by civil law, covers also: co-owners, perpetual usufructuaries or other entities in possession of real estate. Consequently, the source of the obligation to ensure maintenance lies in the broadly understood relationship with the property itself. The legal status of owners and users of building structures is shaped not only by the rights and obligations resulting from the provisions of the Act, but also by the rights and, to an even greater extent, obligations of public and legal nature. $^{27}$ The scope of legal regulation of the maintenance of building structures is directly binding for the owners and users.

The maintenance of a building structure in good repair is prerequisite for ensuring safety of its use and durability. The proper technical condition of a building structure is a state which conforms to the applicable construction law regulations, including technical and construction regulations, together with the applicable Polish standards and principles of technical knowledge. ${ }^{28}$ There are two kinds of processes when a building structure is in use. The first process is associated with a constant decrease in the performance of the building and the second one is related to constantly growing demands of the users of the building. While the first process relates to the question of wear and tear, the other process results from so-called new challenges, such as social, market and economic considerations. They are manifested by expectations of higher living standards, changed lifestyles, technical progress or the desire to improve the internal environment of a building structure, that is working or housing conditions. The increased level of such requirements entails improved safety and comfort and reduced costs of maintenance. ${ }^{29}$ In order to ensure the proper technical condition without compromising many parameters that determine the safety, durability and the effectiveness of existence and operation of a particular facility, the legislator obliges the appropriate

\footnotetext{
${ }^{27}$ According to the Supreme Court, a public-law limitation of the ownership right is the fact that relevant documents related to a construction object are stored and made available, which is an act exceeding the ordinary management of a co-owned thing (Article 199 of the Civil Code), see the Judgement of the Supreme Court of 20 June 2002, file ref. no. I CKN 748/2000.

${ }^{28}$ C. WoźNIAK, "Komentarz do art. 61," in Prawo budowlane z umowami $w$ działalności inwestycyjnej, ed. H. Kisilowska (Warszawa: LexisNexis, 2008), 294.

${ }^{29}$ ORŁOWSKI, "Wybrane aspekty," 36-37.
} 
entities to properly maintain and use the building structure. Pursuant to Article $61 \mathrm{CL}$, the owner or manager of the construction work is obliged to maintain and use a building structure. ${ }^{30}$ They must maintain the state of the structure in such a way that it ensures safety and fulfils the intended purposes. At this point, we should add that these obligations apply only to building structures which have been constructed and are used in accordance with the provisions of the Construction Law. ${ }^{31}$

A building structure in use should be maintained in a proper technical and aesthetic condition in order to prevent excessive deterioration of its functional properties and technical efficiency, especially in terms of meeting the requirements for a building structure as such. ${ }^{32}$ These requirements should already be ensured in the building design and execution of a building structure in the manner prescribed by law, especially in the case of technical construction, and in accordance with the principles of technical knowledge. It is therefore appropriate to provide that the relevant activities at the use phase of a building structure should be carried out by the owner and manager on the basis of technical building regulations and principles of technical knowledge. ${ }^{33}$

The basic requirements for each building structure are:

1) safe internal structure

2) fire safety

3) safety of use

4) adequate hygienic and health conditions as well as environmental protection

5) protection against noise and vibrations

6) adequate energy performance and optimisation of energy use.

In addition to complying with the basic requirements, a building structure must also comply with certain operating conditions in accordance with the intended use of such a structure, in particular:

1) the supply of water and electricity and, as appropriate, of heat and fuels, assuming that these factors are used efficiently

\footnotetext{
${ }^{30}$ The provision of Article 61 of the Civil Code defines the legal obligation of the owner and manager of a building structure and limits, in a sense, their authority over the property. This is because it excludes any arbitrary use of the entity that is in possession of the building structure. W. MISIAK, Poradnik inwestora budowlanego (Warszawa: Polskie Centrum Budownictwa, 1997), 115.

${ }^{31}$ Judgement of the Supreme Administrative Court of 7 April 2005, file ref. no. III CKN 1399/04, LEX no. 169366.

${ }^{32}$ E. JanisZewsKa-Kuropatwa, "Komentarz do art. 61," in Prawo budowlane, ed. Z. Niewiadomski, 618.

${ }^{33}$ Ibid., 622-23.
} 
2) disposal of sewage, rainwater and waste

3) possible access to telecommunications services, in particular broadband Internet

4) the possibility to maintain a proper technical condition

5) necessary conditions for the use of public utility buildings and multifamily residential buildings by disabled persons, in particular persons in wheelchairs

6) work health and safety conditions

7) protection of the inhabitants as required by civil defence

8) protection of structures entered in the register of monuments and structures under conservation protection

9) proper location on the building plot

10) respect for the reasonable interests of third parties existing in the area of the structure's impact, including assurance of access to a public road

11) conditions of safety and health protection of persons staying on the construction site.

The use of a building structure, in accordance with the above requirements, in fact also implies its use in accordance with its intended purpose, as set out in the building permit or in the application, but does not rule out the possibility of not physically using it. ${ }^{34}$ In particular, we should note that the obligation imposed on the owner or manager of the building structure to ensure with due care the safe use of the work in case of external factors affecting the work related to human activities or natural forces such as: lightning, seismic shocks, strong winds, heavy rainfall, landslides, ice phenomena on rivers and seas, lakes and water bodies, fires or floods resulting in damage to the building structure or an imminent threat of such damage, which may cause a threat to human life or health, the safety of property or the environment. However, this is not a closed catalogue and other human or natural events that give rise to certain obligations, such as war damage, acts of terrorism, meteorite collapse, are also possible. In the event of such extreme phenomena, the range of obligatory tasks should include actions limiting the damage to the building structure or an imminent danger of such damage, which may threaten the life or health of people, the safety of property and the environment. ${ }^{35}$

One of the basic instruments for the proper maintenance of construction works is the imposition on the owner or manager of obligations related to

\footnotetext{
${ }^{34}$ Ibid., 618-19.

${ }^{35}$ Ibid., 619-20.
} 
periodic inspections carried out pursuant to Article 62 of the Civil Code. These obligations consist chiefly in carrying out periodic inspections and assessments of the technical condition of the facility during its use and in undertaking actions related to the performance of necessary maintenance and repair works to ensure the assurance of the proper technical state and safety of the facility in operation. From the point of view of the importance of building control, in addition to the broadly understood safety assurance of their users, checks are aimed at verifying the actual state in terms of proper implementation of the imposed obligations. ${ }^{36}$ In accordance with Article 61 of the Civil Code, the owner or manager of a building structure are obliged to maintain and use it in accordance with its designation and requirements of environmental protection and to maintain them in a proper technical and aesthetic condition and ensure, while observing due diligence, safe use of the facility in the event of external factors that may lead to its damage, causing a threat to life or health of people, the safety of property and the environment. Therefore, it is the primary duty of the owner or manager to periodically inspect the structure, namely:

1) once a year with respect to those elements of buildings which are exposed to harmful weather effects, installations for the protection of the environment, as well as gas installations and chimney ducts

2) once every 5 years with respect to the technical efficiency and utility of the whole building, as well as its the aesthetics and surroundings

3) at least twice a year, until May 31 and November 30, for buildings with a building area exceeding $2000 \mathrm{~m}^{2}$ and other facilities with a roof area exceeding $1000 \mathrm{~m}^{2}$.

Consequently, obligations thus defined lead to the following conclusions. In a normal situation, not caused by natural or human forces, the owner of the building structure is obliged to maintain it in a good technical and aesthetic state. However, in a crisis situation, caused by natural or human factors, the owner of the facility is obliged to ensure safety of its use by applying technical and operational measures appropriate to the state of emergency. The owner of the facility should be prepared for such an eventuality in the formal and factual sense, which is important for the obligation to preserve people, property and the environment in each facility, and in particular in a public utility building.

\footnotetext{
${ }^{36}$ M. PELJAN, "Zakres podmiotowy i przedmiotowy kontroli obiektów budowlanych," Samorzad Terytorialny 11 (2008): 70.
} 
When analysing the obligations, we can say that the scope of the expected activity of the entities mentioned above is determined by "due diligence." The benchmark for the obligations imposed will be an objective measure of diligence, namely such that the can be expected of any owner in a given situation. The owner of the building structure does not therefore have to prevent any negative externalities, but should try to remedy any reasonably foreseeable and counteractable event. ${ }^{37}$

\section{CONFORMITY OF THE OBLIGATIONS WITH THE POLISH CONSTITUTION}

Attention should be paid to the question of the actual imposition of obligations on owners and managers and the possible financial burden of their proper implementation. Obviously, we cannot question the authorisation to limit the rights and freedoms of citizens by imposing additional obligations on them, but such restrictions on the use of building structures can only be imposed as much as necessary and in a strict proportion between the degree of infringement of the individual's interest and the rank of the public interest to be protected and the constitutional principles to be respected. An assessment whether the ban on excessive interference with civil rights and freedoms has been infringed should also answer the question whether the restrictions imposed on individuals with regard to the obligations imposed are commensurate with the objective of the proper use of a building structure. Restriction of rights and freedoms in the name of interest recognised by the legislator as deserving special protection has been the subject of numerous deliberations of the Constitutional Tribunal. The Tribunal reasoned that the rights and freedoms of an individual may be limited only if it is allowed under constitutional provisions; limitations may be introduced only to the extent necessary and must be treated as exceptions; neither individual limitations nor their sum may infringe the essence of the rights or freedoms subjected to them. ${ }^{38}$

\footnotetext{
${ }^{37}$ B. LATos, Utrzymanie budynków administracji publicznej $w$ należytym stanie techniczno-użytkowym (Wrocław: Presscom, 2013), 30-31.

${ }^{38}$ See the Resolution of the Constitutional Tribunal of 2 March 1994, file ref. no. W. 3/93, OTK of 1994, Part I, 158-59; Judgement of the Constitutional Tribunal of 26 April 1995, file ref. no. K 11/94, OTK of 1995, Part I, 132.
} 
The legislator's objective is to create regulations that would guarantee the proper maintenance of building structures. As argued in the discussion on the amendments to the Construction Law of 2007, the need to introduce obligations results from the necessity to maintain and increase the level of safety of using building structures. The tragic events of 2006 associated with the building disaster in Katowice showed that there is a need not only to clarify certain provisions concerning the obligations of owners and managers of buildings, but also to introduce new-so far not directly articulatedinspections of buildings. As a result, in order to counteract such events, regulations were introduced aimed at improving the safety of use of existing multi-spatial buildings, in particular public utility buildings.

It should be remembered, however, that with legal regulations imposing specific obligations that affect the limits of interference with civil rights and freedoms, the content of Article 31 para. 3 of the Constitution, according to which it is essential for such interference that such restrictions are introduced only in the Act. ${ }^{39}$ They shall not affect the essence of freedoms and rights. Furthermore, their introduction should be supported by important and well-defined categories of public interest, namely security, public order, protection of the environment, public health and morals, or the freedoms and rights of others. ${ }^{40}$ The content of this provision gives rise to an extremely important-from the perspective of public order-principle of proportionality ${ }^{41}$ the substance of which falls within the limits set by the wording of this provision. The limits of this interference are determined by a system of values protected by the supreme law and a balanced relationship between the public interest and the interest of the individual. ${ }^{42}$ The requirement to balance the

\footnotetext{
${ }^{39}$ It should be added, however, as the Constitutional Tribunal sees it, Article 31 para. 3 of the Constitution cannot constitute an entirely independent model of control. It must always be regarded as a dependent provision applied in conjunction with other provisions of the Constitution that regulate specific freedoms or laws. K. WóJTOwicz, "Zasada proporcjonalności jako wyznacznik konstytucyjności norm," in Księga XX-lecia orzecznictwa Trybunału Konstytucyjnego, ed. M Zubik (Warszawa: Office of the Constitutional Tribunal, 2006), 276.

${ }^{40}$ It is necessary for the principle of proportionality to apply to establish that the interference of public authorities serves to implement one or more of the values set out in the Constitution. See the Judgement of the Constitutional Tribunal of 11 December 2008, file ref. no. SK 12/08, OTK-A of 2008, no. 10, item 176.

${ }^{41}$ M. ZDYB, J. Stelmasiak, and J. SZREniawski, "Zasada proporcjonalności w świetle Konstytucji RP," in Podmioty administracji publicznej i prawne formy ich dziatania. Studia i materiaty $z$ konferencji jubileuszowej profesora Eugeniusza Ochendowskiego (Toruń: Towarzystwo Naukowe Organizacji i Kierownictwa „Dom Organizatora”, 2005), 471.

${ }^{42}$ Z. Duniewska et al., Prawo administracyjne. Pojęcia, instytucje, zasady w teorii i orzecznictwie (Warszawa: Wydawnictwo Difin, 2009), 111. It should be noted that in the presented
} 
two interests requires not so much that a certain proportion be struck between the purpose of the interference and its consequences for individual rights as that the decision-making authority weighs up the interests at stake, so that decisions are rational and avoid gross disparities. ${ }^{43}$ This regard for both interests is intended to cause that by applying the procedure set out in the Code of Administrative Procedure the administration will interfere with subjective rights on the basis of objective truth, in a balanced manner, in accordance with the competences, only to the extent necessary. ${ }^{44}$

In attempting to evaluate the proportionality of legal regulation of the use of building structures, ${ }^{45}$ the following three questions should be answered: 1. Can the introduced legislative regulation achieve the intended results? 2. Is the regulation necessary to protect the public interest to which it is linked? 3. Is the effect of the introduced regulation commensurate to the burden it imposes on the citizen $?^{46}$

We should see that particular emphasis was laid on the criterion of necessity in a democratic state with the rule of law. This means that any restriction of the rights and freedoms of the individual must first of all be assessed in terms of whether it was necessary or whether the same objective could not be achieved by other methods which are less onerous for the citizens because they do not interfere less with the sphere of rights and freedoms. ${ }^{47}$ In general, the prohibition of excessive interference has a protective function in relation to all rights and freedoms, bearing in mind that the criteria of excessive interference must be made relative, inter alia, given the character of individual rights and freedoms. ${ }^{48}$ This ban is one of the manifestations of the principle of citizens' trust in the state, and thus one of the requirements that a democratic state governed by the rule of law imposes on its bodies. ${ }^{49}$ The

approach, the balance between the public interest and the individual interest means that some dilemma, some contradictions or difference between these interests must be resolved.

${ }^{43}$ D.R. KiJowsKi, "Zasada adekwatności w prawie administracyjnym," Państwo i Prawo 4 (1990): 65.

${ }^{44}$ T. SiEnKIEwICZ, Pozwolenie w ochronie zabytków (Lubin, Wydawnictwo KUL, 2013), 60.

${ }^{45}$ According to Zbigniew Leoński, the proportionality assessment must take account in particular of the aspects of legislation and practice. LEOŃSKI, Zasada wolności budowlowej, 144.

${ }^{46}$ Judgement of the Constitutional Tribunal of 5 November 1997, file ref. no. K 22/97, OTK of 1997 , nos. 3-4, item 41 .

${ }^{47}$ Judgement of the Constitutional Tribunal of 12 January 1999, file ref. no. P 2/98.

${ }^{48}$ M. ZDYB, "Administracyjnoprawne ograniczenia praw rzeczowych," in System prawa administracyjnego. Prawo administracyjne materialne, ed. R. Hauser, Z. Niewiadomski, and A. Wróbel (Warszawa: Wydawnictwo C.H. Beck, 2012), 7: 572.

${ }^{49}$ Decision of the Constitutional Tribunal of 26 April 26 1995, file ref. no. K 11/94. 
requirement of proportionality will be satisfied where the number of advantages stemming from a restriction exceeds the number of disadvantages of the restriction imposed, making it necessary to consider the relationship between purpose and means, even if the measures employed are useful and necessary for attaining the objective, provided that they are not justified by the importance and nature of the objective. ${ }^{50}$

Moreover, we should bear in mind that the proportionality of regulations is to take into account the requirements of a democratic state of law, ${ }^{51}$ which are based on the common will of individuals, guaranteeing everyone the possibility of developing his or her personality unimpeded by redundant interference from public authorities, taking into account not only the scale and severity of a given regulation, but also the public interest in maintaining the widest possible range of civil rights and freedoms. Their protection is not only an individual interest, but also one of the main tasks of public authority. ${ }^{52}$

When assessing the proportionality of regulation, the level of interference exerted by administrative authorities with the freedom to use building structures ranges from the mildest to the most extreme. Interference in the sphere of freedom of use of the construction work occurs in various ways using means of appropriate content, including the setting of deadlines, conditions and other stipulations.

A gradual increase in interference should also be accompanied by correspondingly more stringent requirements as regards proportionality. A greater threat to the protection of the public interest implies stricter restrictions on the freedom of use of a building structure. ${ }^{53} \mathrm{We}$ can therefore assume that the State has the power to impose certain burdens regulated by public law on the owners or managers of works, but only on condition that it is a measure necessary to achieve the general objective of the proper use of building structures. ${ }^{54}$ It cannot happen that by way of administrative actions obligations are imposed on the owner or manager of a building structure which should not be borne by him and which are only a bureaucratic burden detached from the purpose for which they are to be used.

\footnotetext{
${ }^{50}$ J. ZAKOLSKA, Zasada proporcjonalności w orzecznictwie Trybunału Konstytucyjnego (Warszawa: Wydawnictwo Sejmowe, 2008), 27-28.

${ }^{51}$ Judgement of the Constitutional Tribunal of 7 February 2001, file ref. no. K 27/00, OTK of 2001, no. 2, item 29.

${ }^{52}$ D.R. KıJowsKI, Pozwolenia w administracji publicznej (Białystok: Temida 2, 2000), 282.

${ }^{53}$ Ibid., 278.

${ }^{54}$ See A. WALASZEK-PyzıoŁ, "Zasada proporcjonalności w orzecznictwie Trybunału Konstytucyjnego," Przegląd Ustawodawstwa Gospodarczego 1 (1995): 22.
} 
It seems that all the existing restrictions on the freedom to use a building structure are both useful measures and necessary for the realisation of the public interest. Indeed, if all restrictions are removed from the use of building structures thus depriving the State of indispensable means of control, public order, life and health of citizens, as well as international and legal obligations of the Polish state could be jeopardised, for example in the area of energy efficiency of buildings. ${ }^{55}$

In the opinion of the Constitutional Tribunal, in the case of collision of goods, property rights and cleanliness and aesthetics of the place of residence, the latter group ${ }^{56}$ should prevail. Therefore, it must be recognised that the obligations imposed on owners and managers with respect to the maintenance of building structures do not materially infringe the principles of property protection, and thus do not infringe ownership in the economic sense. Analysing the previous body of judicial decisions of the Constitutional Tribunal, it can be stated that the above obligations do not violate the rights and freedoms of citizens. The necessity of limitation stems from the imperative to ensure public security and order in the State and from the need to protect the environment, public health and morals and the necessity to protect the freedoms and rights of others. Consequently, the indication for a legal restriction of the freedom of construction is a specific, qualified type of public interest, namely "important" interest. ${ }^{57}$

\section{CONCLUSION}

In conclusion, it should be said that restrictions on the freedom to use building structures, despite their abundance in numerous laws, fall within the limits of the freedom of construction. Therefore, it can be assumed that the obligations of the owner and manager of a building structure under the existing legislation are consistent with the principle of freedom of construction developed by the doctrine. The purpose of these obligations is to protect values that are important both for the public and individual interest. In particular, these obligations, seen in the context of rights and freedoms, serve

\footnotetext{
${ }^{55}$ See the Judgement of the Constitutional Tribunal of 10 October 2001, file ref. no. K 28/01, OTK of 2001, no. 7, item 212.

${ }^{56}$ Judgement of the Constitutional Tribunal of 5 November 1997, file ref. no. K22/97.

${ }^{57}$ Judgement of the Constitutional Tribunal of 8 July 2008, file ref. no. K 46/07, OTK-A of 2008, no. 6, item 104 .
} 
primarily to safeguard the public interest. However, the existence of obligations that prescribe that the owner or manager of a building structure undertake a specific measure comes as no surprise. It seems that with this concept a healthy compromise is sought between the frequently conflicting interests of the owner or manager of the facility and the public interest. It should be stressed that the obligations arising from the statutory laws are based, among others, on considerations of safety, environmental protection, preservation of historical monuments, or energy efficiency. We can say, then, that they serve the public interest and are created only by the legislator. In other words, they are consequences of public subjective law, which originates in an act that has the rank of a statute.

\section{BIBLIOGRAPHY}

SOURCES OF LAW

Constitution of the Republic of Poland of 2 April 1997. Journal of Laws of 206, No. 78, item 483, as amended.

Ustawa z dnia 7 lipca 1994 r. Prawo budowlane [Act of 7 July 1994 - The Construction Law]. Journal of Laws 2017, item 1332, as amended.

\section{CASE LAW}

Resolution of the Constitutional Tribunal of 2 March 1994, file ref. no. W. 3/93. OTK [Rulings of the Constitutional Tribunal] of 1994, Part I.

Decision of the Constitutional Tribunal of 26 April 1995, file ref. no. 11/94. OTK of 1995, Part I.

Judgement of the Constitutional Tribunal of 8 July 1997, file ref. no. SK 22/97. OTK of 1997, No. 3-4, item 41.

Judgement of the Constitutional Tribunal of 12 January 1999, file ref. no. P 2/98. OTK of 1999, No. 1 , item 2.

Judgement of the Constitutional Tribunal of 7 February 2001, file ref. no. K 27/00. OTK of 2001, No. 2, item 29.

Judgement of the Constitutional Tribunal of 10 October 2001, file ref. no. K 28/01. OTK of 2001, No. 7, item 212.

Judgement of the Constitutional Tribunal of 8 July 2008, file ref. no. K 46/07. OTK-A of 2008, No. 6, item 104.

Judgement of the Constitutional Tribunal of 11 December 2008, file ref. no. K 12/08. OTK-A of 2008, No. 10, item 176.

Judgement of the Constitutional Tribunal of 10 October 2011, file ref. no. Kp 7/09. OTK-A of 2001, No. 3, item 26.

Judgement of the Supreme Court of 20 June 2002, file ref. no. I CKN 748/2000. OSNC [Judgements of the Supreme Court, Civil Division] No. 12, item 163. 
Judgement of the Supreme Administrative Court of 7 April 2005, file ref. no. OSK 1399/04, LEX no. 169366.

Judgement of the Supreme Administrative Court of 23 February 2007, file ref. no. II OSK 354/06, LEX no. 505624.

Judgement of the Supreme Administrative Court of 18 January 2008, file ref. no. II OSK 1876/06, LEX no. 508458.

Judgement of the Voivodeship Court of Appeal in Warsaw of 22 May 2007, file ref. no. VII SA/Wa 2298/06, LEX no. 336729.

Judgement of the Voivodeship Court of Appeal in Kielce of 29 April 2013, file ref. no. II SA/Kr 144/13, LEX no. 1325739.

\section{BIBLIOGRAPHY}

ASman, Tomasz, and Zygmunt Niewiadomski. "Komentarz do art. 4.” In Prawo budowlane. Komentarz, edited by Zygmunt Niewiadomski, 88-115. Warszawa: Wydawnictwo C.H. Beck, 2011.

CZARniK, Zbigniew. "Miejscowy plan zagospodarowania przestrzennego jako podstawa wykonywania własności nieruchomości." Zeszyty Naukowe Sądownictwa Administracyjnego 2 (2006): 43-51.

Duniewska, Zofia, Barbara Jaworska-DęBska, Ryszarda Michalska-Badziak, Ewa OlejniCZAK-SZAŁowsKa, and Małgorzata Stahl. Prawo administracyjne. Pojęcia instytucje, zasady w teorii orzecznictwa. Warszawa: Wydawnictwo Difin, 2009.

JAKIMOWICZ, Wojciech. "Konstrukcja i istota wolnościowego prawa do zabudowy." Samorząd Terytorialny 6 (2005): 47-62.

JAKIMOWICZ, Wojciech. "Przestrzeń prawna wolności zabudowy." In Przestrzeń w prawie administracyjnym. III krakowsko-wroctawskie spotkanie naukowe administratywistów, edited by Jan Zimmermann, 46-75. Warszawa: Wolters Kluwer Polska, 2013.

JAKIMOWICZ, Wojciech. Wolność zabudowy w prawie administracyjnym. Warszawa: Wolters Kluwer Polska, 2012.

Janiszewska-Kuropatwa, Elżbieta. "Komentarz do art. 61." In Prawo budowlane. Komentarz, edited by Zygmunt Niewiadomski, 618-24. Warszawa: Wydawnictwo C.H. Beck, 2011.

KıJowski, Daniel. Pozwolenia w administracji publicznej. Białystok: Temida 2, 2000.

KıJowsKi, Daniel. "Zasada adekwatności w prawie administracyjnym.” Państwo i Prawo 4 (1990): 62-71.

KisılowsKa, Helena, and Dominik SyPNIEwSKI. Prawo budowlane. Warszawa: LexisNexis, 2012.

KostKa, Zdzisław. Prawo budowlane. Komentarz. Gdańsk: Ośrodek Doradztwa i Doskonalenia Kadr, 2005.

KRUSZYŃSKA-KoŚMICKA, Małgorzata, and Maciej KRUŚ. "Prawne ograniczenia wolności budowlanej." In Prawo wobec wyzwań wspótczesności, edited by Bartosz Guzik, Natalia Buchowska, and Paweł Wiliński, 6: 386-97. Poznań: Biuro Usługowo-Handlowe "PRINTER," 2010.

LASKOwSKA, Małgorzata. "Ochrona interesów sąsiadów w procesie budowlanym po nowelizacji." Samorząd Terytorialny 5 (2004): 47-58.

LATos, Bartosz. Utrzymanie budynków administracji publicznej w należytym stanie techniczno-użytkowym. Wrocław: Presscom, 2013. 
LeOŃSKI, Zbigniew, and Marek SZEwCZYK. Podstawowe instytucje planowania przestrzennego i prawa budowlanego. Poznań: Wydawnictwo Wyższej Szkoły Bankowej, 1999.

LEOŃSKI, Zbigniew. Materialne prawo administracyjne. Warszawa: Wydawnictwo C.H. Beck, 2005.

LEOŃSKI, Zbigniew. "Zasada wolności budowlanej i jej administracyjnoprawne ograniczenia." In Rola materialnego prawa administracyjnego a ochrona praw jednostki, edited by Zbigniew Leoński, 140-46. Poznań: Wydawnictwo Wyższej Szkoły Bankowej, 1998.

MAJCHRZAK, Bartosz. Procedura zgłoszenia robót budowlanych. Warszawa: Wolters Kluwer, 2008.

MĄCZYŃSKI, Andrzej. "Prawo do mieszkania w świetle Konstytucji RP." In Godność człowieka a prawa ekonomiczne $i$ socjalne. Ksiegga jubileuszowa wydana $w$ piętnasta rocznice ustanowienia Rzecznika Praw Obywatelskich, 142-54. Warszawa: Wydawnictwo RPO, 2003.

MisIAK, Wojciech. Poradnik inwestora budowlanego. Warszawa: Polskie Centrum Budownictwa, 1997.

NiEWIADOMSKI, Zygmunt, and Tomasz Asman. "Wolność budowlana jako prawo podmiotowe inwestora." In Księga jubileuszowa profesora Stanisława Jędrzejewskiego, edited by Henryk Nowicki and Wojciech Szwajdler, 568-82. Toruń: Towarzystwo Naukowe Organizacji i Kierownictwa "Dom Organizatora", 2009.

ORŁOWSKI, Zygmunt. "Wybrane aspekty właściwości użytkowych budynku w okresie jego eksploatacji." Przeglad Budowlany 10 (2011): 36-43.

PELJAN, Michał. "Zakres podmiotowy i przedmiotowy kontroli obiektów budowlanych." Samorzad Terytorialny 11 (2008): 68-79.

PiĄTEK, Wojciech. "Komentarz do art. 4." In Prawo budowlane. Komentarz, edited by Andrzej Gliniecki, 54-57. Warszawa. Wolters Kluwer, 2012.

Prawo gospodarcze. Zagadnienia administracyjnoprawne, edited by Marek Wierzbowski and Mirosław Wyrzykowski. Warszawa: LexisNexis, 2015.

PRZYBYSZ, Piotr. "Obowiązek administracyjny_pojęcie, rodzaje, konkretyzacja.” Organizacja-Metody-Technika 8-9 (1990): 14-19.

SIENKIEwICZ, Tomasz. Pozwolenie w ochronie zabytków. Lublin: Wydawnictwo KUL, 2013.

SYPNIEWSKI, Dominik. "Deregulacja procesu inwestycyjno-budowlanego. Ograniczenie reglamentacji robót budowlanych." Przeglad Prawa Publicznego 2 (2013): 67-79.

SYPNIEWSKI, Dominik. Nadzór nad procesem budowlanym. Warszawa: LexisNexis, 2011.

SZRENIAWSKI, Piotr. Obowiazek w prawie administracyjnym. Lublin: Wydawnictwo WSPA, 2014.

WALASZEK-PYZIOŁ, Anna. "Zasada proporcjonalności w orzecznictwie Trybunału Konstytucyjnego." Przeglad Ustawodawstwa Gospodarczego 1 (1995): 22-24.

WASILEWSKI, Andrzej. "Administracja wobec prawa własności nieruchomości gruntowych. Rozważania z zakresu nauki prawa administracyjnego." Zeszyty Naukowe Uniwersytetu Jagiellońskiego 54 (1972): 52-63.

WoźNIAK, Cezary. "Komentarz do art. 61." In Prawo budowlane z umowami w działalności inwestycyjnej, edited by Helena Kisilowska, 294-95. Warszawa: LexisNexis, 2008.

WóJTowicz, Krzysztof. “Zasada proporcjonalności jako wyznacznik konstytucyjności norm.” In Księga XX-lecia orzecznictwa Trybunatu Konstytucyjnego, edited by Marek Zubik, 273-88. Warszawa: Biuro Trybunału Konstytucyjnego, 2006.

ZAKolsKa, Joanna. Zasada proporcjonalności w orzecznictwie Trybunatu Konstytucyjnego. Warszawa: Wydawnictw Sejmowe, 2008. 
ZAMYŚLEWSKA-GORZĄCH, Krystyna. "Wolność budowlana i jej prawne ograniczenia." Samorząd Terytorialny 10 (2005): 57-64.

ZDYB, Marian, Jerzy STELMASIAK, and Jan SzRENIAWSKI. "Zasada proporcjonalności w świetle Konstytucji RP.” In Podmioty administracji publicznej i prawne formy ich działania. Studia i materiaty z konferencji jubileuszowej profesora Eugeniusza Ochendowskiego, 470-77. Toruń. Towarzystwo Naukowe Organizacji i Kierownictwa "Dom Organizatora", 2005.

ZDYB, Marian. “Administracyjnoprawne ograniczenia praw rzeczowych.” In System prawa administracyjnego. Prawo administracyjne materialne, edited by Roman Hauser, Zygmunt Niewiadomski, and Andrzej Wróbel, 7: 561-646. Warszawa: Wydawnictwo C.H. Beck, 2012.

ZDYB, Marian. Wspólnotowe i polskie prawo publiczne. Vol. 1, Wolność i reglamentacja działalności gospodarczej. Handel zagraniczny. Warszawa: Wolters Kluwer, 2008.

\section{THE FREEDOM OF CONSTRUCTION AND OBLIGATIONS TO MAINTAIN BUILDING STRUCTURES}

\section{Summary}

The subject of the study is the issue of freedom of construction, shown against the background of obligations relating to the maintenance of buildings. The source of building freedom is the constitutional principle of property protection, which provides the owner with protection against unlawful infringement of his rights and excessive power of public administration bodies. However, the exercise of building freedom does not mean complete freedom in the use of the building structure, because it has its limits outlined in the implementation of the values indicated in the Constitution of the Republic of Poland. The study analyses the compliance of obligations concerning the maintenance of building structures with the Constitution of the Republic of Poland.

Key words: building structure; construction law; owner and manager; principle of proportionality.

Translated by Tomasz Patkowski

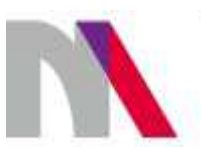

The preparation of the English version of Roczniki Nauk Prawnych (Annals of Iuridical Sciences) and its publication in electronic databases was financed under contract no. 836/PDUN/2018 from the resources of the Minister of Science and Higher Education for the popularization of science. 